\title{
Responding to the Educational Challenges and Opportunities of ASEAN Integration: A Case Analysis of St. Paul University Philippines
}

\author{
Sr. Merceditas Ang, SPC \\ ${ }^{1}$ St. Paul University Philippines, Philippines \\ Correspondence: Merceditas Ang, St. Paul University Philippines, Philippines.
}

Received: November 17, 2017

Accepted: December 12, 2017 Online Published: December 18, 2017

doi:10.20849/aes.v2i4.257

URL: https://doi.org/10.20849/aes.v2i4.257

\begin{abstract}
This paper discusses the challenges and opportunities to the education sector of the ASEAN Regional Integration launched in 2015. The Philippine education was subjected to reforms and transitions due to the K to 12 Basic Education Enhancement Program of adding two years of Senior High School. Consequently, the Higher Education Institutions suffered setbacks, decrease in enrolment and displacement of teachers. The case of St. Paul University Philippines portrays the educational strategies and activities of meeting these challenges and taking advantage of the opportunities at hand. Of foremost consideration to the successful experience of SPUP are its internationalization program, the convergence of cultural and religious differences, and the citizenship and character components of its Paulinian education. These were supported by policy and organizational structures, curriculum reviews, new learning modalities, international partnerships and linkages, global learning, and practice of inter-cultural competence. The internationalization of SPUP is a positive response to the ASEAN Integration.
\end{abstract}

Keywords: internationalization, ASEAN integration, inter-cultural competence

\section{Introduction}

In January 2015, the Association of Southeast Asian Nations (ASEAN) Regional Integration was launched in the Philippines. This jumpstarted the study about the areas of collaboration and integration among the ten member countries composed of: Brunei, Cambodia, Indonesia, Laos, Malaysia, Myanmar, Philippines, Singapore, Thailand, and Vietnam. The three ASEAN pillars were also highlighted, namely: Political Security, Economic Community, and Socio-Cultural Community. Central to the blueprint of ASEAN Socio-Cultural Community is the "significance of education in promoting people's well-being and human dignity." (Club, L., 2016) Accordingly, the Filipino educators and policy makers were confronted with the challenges and opportunities ushered in by the ASEAN Integration. This opened the doors towards seamless education and increased the international mobility and cultural diversity of learners. As aptly put by an educator, "Traditionally, the domain of knowledge and education are within the four corners of the classroom. But in this stage of time, the increasing international student mobility, deepening research cooperation and networks are blurring territorial boundaries in learning and scholarship. These trends present opportunities and tools that accelerate regional harmonization in Southeast Asia." (Macarans, F., 2015) As an offshoot, the education sector was shaken by reforms and transitions.

The Philippine schools were subjected to educational reforms brought about by the $\mathrm{K}$ to 12 Basic Education Enhancement Program which took effect in 2016. The additional two years of Grades 11 and 12 for Senior High School met the criteria of the Asian nations in the number of years of basic education, from 10 to 12 years (Torno, B., 2017). However, the transition was not easy for the colleges and universities that had no first year college enrolment in SY 2016-2017, and no first and second year enrolment for SY 2017-2018. The tremendous decrease of enrolment in higher education has caused problems in terms of retrenchment and displacement of college faculty and the school's sustainability. The Commission on Higher Education (CHED) offered scholarships and research grants to assist displaced faculty, and spearheaded the internationalization and quality assurance of Higher Education Institutions (HEI) to be on par with counterparts in the ASEAN and other countries (Berse, P., 2017). Several schools synchronized the academic calendar with ASEAN universities to 
accommodate the mobility of the faculty and students (Pacete, V., 2015). The ASEAN economic sector has placed on education the role of ensuring the competencies and employability of the students and graduates to face the challenges of the global economy in the $21^{\text {st }}$ century (Del Rosario, R., 2015). This milestone in education has brought colourful experiences among schools.

It is in this context that St. Paul University Philippines (SPUP) has strategically managed to survive and thrive. SPUP is a Catholic autonomous university. Its enrolment of 6,273 in 2015 has increased to 7,755 in 2017. Also, there was increase of its international partners from only 9 in 2014 to 55 in 2017. This paper discusses the challenges and opportunities faced by SPUP amid the ASEAN Integration in the areas of internationalization, culture and religion, and citizenship and character formation. The case analysis is anchored on the school's internationalization framework, policy and administrative structures, inter-faith and inter-cultural thrust. What is interesting and noteworthy in the case of SPUP are the strategies and innovations that propelled it to successfully navigate the challenges posed by the ASEAN Integration and the educational reforms and transitions.

\section{Internationalization Program and Initiatives}

In response to the challenges and opportunities of the ASEAN Regional Integration, SPUP launched its internationalization program and initiatives in 2015. This is aligned with its vision to be an "internationally recognized institution dedicated to the formation of competent leaders and responsible citizens of their communities, country, and the world." To make it as a policy imperative, internationalization was made as one of the Key Result Areas in the university's Strategic Plan for SY 2015-2018 as prompted by the tagline: Making a difference globally. Organizational re-structuring was undertaken with the creation of new positions, namely, Director for International Relations; Program Coordinator for E-learning and Distance Education, and Director for External Affairs, Alumni and Advocacies. The enabling structures include the excellent educational facilities and permit to accept foreign students, an inter-cultural language institute, dormitories, and a Global Center. Accordingly, the school calendar of SPUP was synchronized with the international schools to facilitate the entry of foreign students and visiting professors.

\subsection{ASEAN Integration at SPUP}

A massive campus-wide information dissemination was conducted on the ASEAN Regional Integration, global education, and internationalization. This was enhanced by lectures, learning activities, ASEAN exhibit and cultural show, food fair, international linkages and networking, etc. The employees organized the ASEAN Tour to visit an ASEAN country every year. The student leaders spearheaded the ASEAN café, SPUP ASEAN Ambassador, and ASEAN trivia and computer games. The reviews of the curricula in both undergraduate and graduate programs had enhanced the international aspects with the incorporation of ASEAN topics and global learning, the study of foreign language as elective, international immersion, student and faculty exchange programs with international partner schools, and embarking on transnational education. Likewise, the blended mode of delivery of instruction and online learning offered in the SPUP Graduate School cater to working foreign students and professionals, as well as Filipino professionals in foreign countries who like to pursue graduate studies. Soon, students from other countries started coming, particularly from Indonesia, East Timor, India, Nigeria, Korea, and Nepal. The international partner schools of SPUP increased rapidly, mostly from Indonesia, Taiwan, Japan, Australia and India. Mobility and plurality of students gained momentum. SPUP was designated by CHED as one of the twelve HEIs to participate in the ASEAN International Mobility of Students (AIMS) Program.

\subsection{Framework for Inter-cultural Competence}

The emerging international community posed as a challenge to the local students in terms of social adjustment, language barrier, and cultural differences. On the other hand, the foreign students encountered problems with food, communication difficulty, stereotyping, culture shock, and social adjustment. The teachers find it challenging to handle international learners in terms of classroom management, teaching approach and strategies, and language barrier for the non-English speakers. Under these conditions, there was a need to develop inter-cultural competence among students and teachers.

A research was conducted on the "Internationalization of St. Paul University Philippines: A Framework to Develop Intercultural Competence for Global Education." (Ang, 2017). The SPUP Framework of Intercultural Competence for Global Education illustrates the interplay of the cognitive, affective, and behavioral dimensions of intercultural competence. Accordingly, the cognitive element comprises of the knowledge, awareness, understanding, study, learning, pre-judgment and bias that are most likely involved in intercultural interactions. The affective element includes the attitudes, values, sentiments, curiosity, openness, care, concern and difficulty that are most likely felt, manifested, and experienced in intercultural interactions. The behavioral aspect 
encompasses the skills, countenance, conduct and gestures that are most likely observed and displayed in intercultural interactions. There are also internal and external outcomes which consist of reflections, insights, results and outputs. The development of intercultural competence is anchored on and ushered by international experience, global learning, and international partnerships and linkages, in the context of SPUP's program and initiatives on internationalization and global education. The thrust towards global education is embedded in the curriculum and instruction, administrative structures, in-campus and off-campus activities, and design of learning environment. The internationalization program of SPUP is propelled by the institutional goal of making a difference globally.

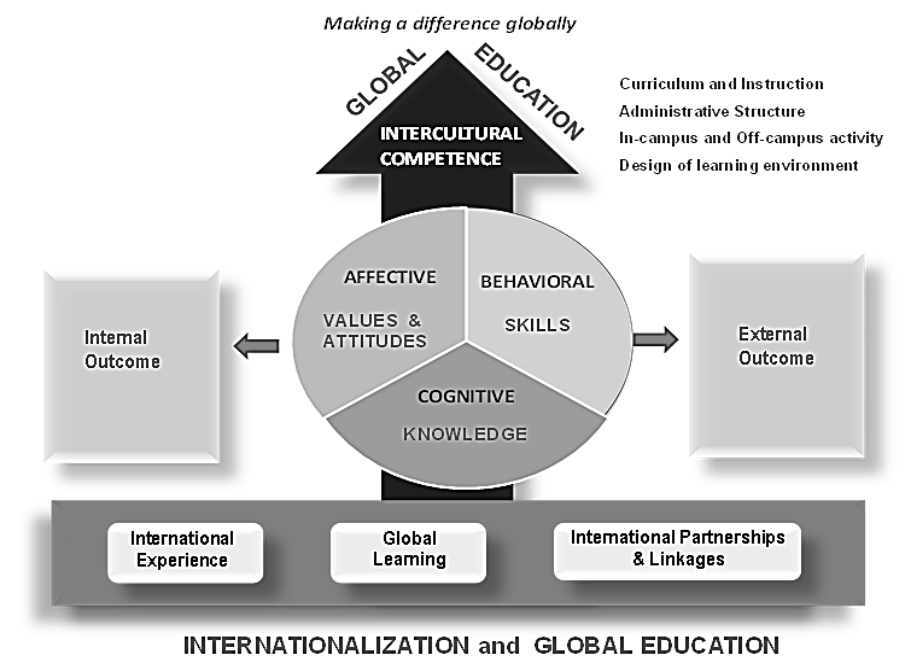

Figure 1. Framework for development of intercultural competence

\subsection{Growth and Expansion}

The internationalization of SPUP has ushered its growth and expansion in terms of increase of partners in the academe, industry, and agencies in the government and private sector. Likewise, it promotes global perspectives among the faculty and students. The local concerns and issues were expanded into a more defined world view. Partnerships and linkages with schools in the ASEAN countries have paved the way for collaborative research, student exchange programs, visiting faculty, immersion, educational trips and seminars. International students enrolled at SPUP either to study for degree programs or take certificate programs in English proficiency. Apparently, the presence of foreign students in the campus has transformed and imbued its milieu with the aura of uniqueness and clout for being the only internationally accredited university in the locality. The Paulinian students of SPUP gained pride and confidence in dealing with foreigners, traveling to other countries for international immersion and exchange programs, and in representing the school in international gathering and summer camp. Consequently, more students were attracted to enrol at SPUP. Thus, the increase in enrolment as shown in Figure 2.

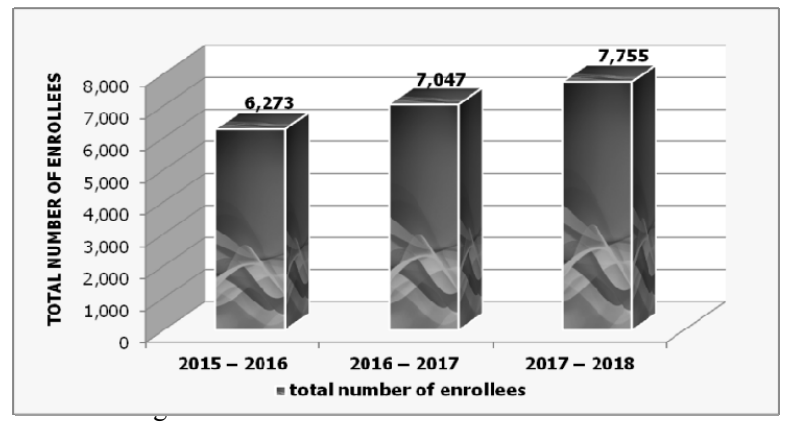

Figure 2. Enrolment profile for SY 2015 - 2017 


\section{Inter-cultural and Inter-religious Convergence}

SPUP is a Catholic university. It upholds religious and academic freedom which is embedded in the school policy and systems. It does not proselytize but promotes inter-faith dialogue. As such, students from various religious affiliations and cultural backgrounds are accepted in fulfillment of the university's mission statement to provide, "optimum access to Paulinian education and service in an atmosphere of compassionate caring without prejudice to race, culture and religious beliefs." The students are mostly Catholics but there are also Muslims, Buddhists, Hindus, Baptists, Protestants and other non-Christian denominations. For worship, there is a chapel for the Catholic and an inter-faith Prayer Room for the non-Catholic.

\subsection{Overcoming Differences in Culture and Religion}

The influx of international students created a challenge in terms of differences in cultural orientations and religious beliefs. The students represent diverse cultural traditions with mixed religions. As expected, they have their own stereotype assumptions, personal bias and prejudices. Complaints and critique mostly pertained to food preference, personal hygiene, wifi access, curfew hours in the dormitory, racial temperament and behaviour, etc. To foster camaraderie among them, the International Students' Day was organized with activities like group dynamics, sports, dancing, singing, food fair, showcase of national costumes and heritage, and inter-faith worship and liturgical celebration. Exercises on inter-cultural competence were conducted to foster openness and acceptance of people who are different in perspectives and nationality. More or less, this paved the way towards respect of one's beliefs, culture, traditions and spirituality.

\subsection{Unity in Diversity}

The international partners of SPUP come from different cultural and religious backgrounds. However, this does not impede the successful and meaningful collaborative endeavors and exchange programs undertaken by the students and faculty. So far, various international research conferences and immersions were held at SPUP participated in by both Christians and non-Christians. These occasions have provided inspiring opportunities for fellowship and collaboration. Indeed, the synergy of the mind and heart can transcend the differences in culture and religion.

SPUP is becoming a hub of spirituality and enculturation for international students. In the campus, there is unity and peaceful co-existence despite cultural diversity. Currently, there are 125 foreign students enrolled in various degree programs and in different levels from elementary to graduate school. Most of them are Indians who are taking up Bachelor of Science in Biology and Doctor of Medicine; the Indonesian are enrolled in Nursing education. The others come from East Timor, Nigeria, Korea, Kenya, USA, Belgium, Papua New Guinea, and Thailand. There are also children of Filipinos overseas workers from Kuwait, Qatar, United Arab Emirates, United States of America, Spain and Oman who prefer to study at SPUP. Table 1 shows the profile of international students.

Table 1. Profile of international students

\begin{tabular}{lccc}
\hline \multicolumn{4}{c}{ FOREIGN STUDENTS } \\
\multicolumn{1}{c}{ YEAR } & $2015-2016$ & $2016-2017$ & $2017-2018$ \\
\hline American & & 1 & 1 \\
Belgian & 2 & 40 & 1 \\
Indian & 15 & 15 & 80 \\
Indonesian & & 1 & 20 \\
Kenyan & 6 & 5 & 8 \\
Korean & 2 & 5 & 6 \\
Nigerian & & 1 & 3 \\
Pn Guinean & & 1 & 1 \\
Thai & 6 & 6 & 5 \\
Timorense & $\mathbf{3 1}$ & $\mathbf{7 5}$ & $\mathbf{1 2 5}$ \\
TOTAL & & &
\end{tabular}




\section{Citizenship and Character Dimensions}

It is the thrust of SPUP to prepare the students and graduates to become globally competent and responsible citizens. The plurality and mobility of millennial learners can be challenging in terms of citizenship and character formation. Yet, it also offers the opportunity for the school to creatively tap the dimensions of service and character in the preparations of the youth to become global citizens. The values of responsible citizenship, respect for human dignity, and moral integrity and uprightness are of prime importance in the total development of the person. Michael Fullan, an educational researcher, has set "character education" as one of the 6Cs for the $21^{\text {st }}$ century teachers and students, together with citizenship, communication, critical thinking and problem solving, collaboration, creativity and imagination (Parker, P., 2014). Based on recent research findings, the Boston-based Center for Curriculum Redesign (CCR) published a Character Qualities Framework that identifies six essential character qualities, to wit: mindfulness, curiosity, courage, resilience, ethics, and leadership. Accordingly, Bialik, Bogan, Fadel, and Horvathova (2015) used the CCR's framework to emphasize character qualities and they argued that "facing the challenges of the 21 st century requires a deliberate effort to cultivate the students' personal growth and the ability to fulfill social and community responsibilities as global citizens."

Paulinian education develops the global competencies of students and graduates with emphasis on: a) character and values; b) citizenship; and c) academic service learning.

\subsection{Character and Value Formation}

Character and value education is imperative in the present era of globalization with its massive consumerism and degeneration of morality (Roy, C., 2011). Thus, the character formation of Paulinians is anchored on five core values: Christ-centeredness, Charity, Community, Charism and Commission. The training and discipline on good manners and personality development focus on love of God and others, justice and peace, environmental stewardship, servant leadership, forgiveness and non-violence. It adheres to a holistic approach that integrates character development in every aspect of school life (Fatoni, A., 2017). There is a need to inculcate among students the human values of peace, truth and right conduct, compassion, non-violence, respect for human life and dignity, love and care of mother earth, and responsible citizenship (UGC, 2003).

In a recent survey conducted among Paulinians, $90 \%$ of the 735 respondents who are college students have affirmed the positive impact of character formation in the development of global competencies. Accordingly, they identified the following character traits as important in order to survive and thrive in a global and complex society: persistent endurance, resiliency, optimism, ethics and morality, faith and hope, openness to change, care for others, self-awareness and self-discipline, social responsibility, personal integrity, mindfulness, honesty and accountability, leadership, patience and tolerance.

\subsection{Citizenship Education}

Citizenship education is an important component of the education ministry. The concept of citizenship is multi-dimensional and inter-disciplinary that touches on national identity, cultural heritage, social belongingness, political and civic participation (Farahani, M.F., 2014). The unprecedented advancement of technology has given rise to a high degree of interconnectivity among people and the world. This has fundamentally changed the nature of social relations. Consequently, such change calls for new forms of citizenship with complex rights and responsibilities in terms of local and global coverage (Rhoades, R. \& Szelényi, K., 2011). Digital citizenship is emerging as a result of a recent emphasis on technology-enabled transformative pedagogy through the 21 st century. It requires greater awareness of the importance of respecting and protecting privacy and information, given the volumes of information to which we have access through digital networks. That is why, at SPUP, the students are taught about responsible use of social media network and cyber security. The students are formed to become responsible global digital citizens. As such, they understand the new global interconnectedness and learn to ethically use technology (Crockett, 2017). This entails the cultivation of values and perspectives that open towards individual and cultural differences and care of the world. A global digital citizen "practices leadership, ethics, global awareness, and personal responsibility. There's no better place to begin nurturing these values within our children than in today's classroom" (Crokett, L.W. and Churches, A., 2017).

In the context of globalization and internationalization, citizenship education is an important facet of the students' overall education. So, the students at SPUP are given opportunities to learn about what it means to be responsible, active citizens, both in the classroom and in the diverse communities to which they belong, within and outside the school. It is important for them to understand that they belong to many communities and that, ultimately, they are all citizens of the global community. Citizenship training covers two aspects: a) local and community-based service learning; and b) global learning and international experience (Ontario's Citizenship Education Framework, 2012). The Paulinian citizenship training involves local and international exposure and 
immersion to poor areas and active participation in socio-civic advocacies like pro-life, peace education, environmental stewardship, good governance, servant leadership, and community outreach projects and services. The students are active members of the SPUP Paulinian Volunteers for Community Development - UNESCO Club. This club was awarded and recognized in good standing by the National Association of UNESCO Clubs in the Philippines ((NAUCP) during the International Assembly of Youth for UNESCO on September 1-3, 2017. Moreover, the President of the club was awarded as Outstanding UNESCO Club Youth Leader.

We also want the students and graduates to become global citizens who feel comfortable in any situation that they are presented with, regardless of where they may be. As such, we teach them to be lifelong learners who are respectful and caring of the people around them. By forming better global citizens, we are trying to create a ripple effect to benefit others outside of the school walls (Finelli, J., 2011). Currently, the students are engaged in serving the marginalized sectors of society like the indigenous people, tenants and farmers who do not own land, abused women and children, prisoners, juvenile delinquents undergoing rehabilitation, orphans and street children.

It is interesting to take note of the responses of 520 Paulinian students in the survey regarding the importance of citizenship in the ASEAN integration and internationalization. The common answers with high frequency of $90 \%$ and above include the following:

Global citizenship develops solidarity with our ASEAN neighbors and the world

Responsible citizens are needed to take good care of people and the earth

Sustainable development is ensured if people become responsible citizens of the world

Internationalization fosters global and digital citizenship

ASEAN citizens need to collaborate and unite as one community

Citizenship is integral in global education

Global citizens are called to promote peace and solidarity among peoples and nations

Global digital citizens create interconnectivity for the good of humanity

Moreover, $88 \%$ of the respondents believe that citizenship education is essential for a successful ASEAN Regional Integration.

\subsection{Academic Service Learning}

Academic service-learning is imbedded in the curriculum and instruction of Paulinian education. It provides the students with an experiential learning pedagogy in which education is delivered by engaging students in community service that is integrated with the learning objectives of core academic curricula, as premised on providing students with contextualized learning experiences that are based on authentic, real-time situations in their local communities. The service learning is based on the skills or specialization taught in the academic program. Table 2 shows the program-based academic service learning of the students.

Table 2. Program-based academic service learning

\begin{tabular}{|c|c|c|}
\hline Program & Academic Service Learning & Beneficiaries \\
\hline Education & Functional literacy and tutorials & Children and adult learners \\
\hline $\begin{array}{lr}\text { Medicine, } & \text { Nursing, } \\
\text { Medical } & \text { Technology, } \\
\text { Pharmacy } & \text { Physical } \\
\text { Therapy } & \end{array}$ & Medical Mission & Sick and handicapped \\
\hline Social Work & Community outreach & Farmers, out-of-school youth \\
\hline Business & Micro-financing & $\begin{array}{l}\text { Unemployed fathers and } \\
\text { mothers }\end{array}$ \\
\hline Information Technology & Computer literacy & Public school pupils \\
\hline $\begin{array}{l}\text { Hotel and Restaurant } \\
\text { Management }\end{array}$ & Cooking lessons & Housewives \\
\hline Religious Education & Catechism & Public school pupils \\
\hline
\end{tabular}




\section{Conclusion}

The case of SPUP demonstrates a positive and dynamic response towards the challenges and opportunities brought about by the ASEAN Regional Integration in the education sector. Whereas, many colleges and universities in the Philippines struggled with the problems of the $\mathrm{K}$ to 12 Transition which caused decrease in enrolment, deficit in revenues, displacement of teachers, unused classrooms, closure of program offerings and indebtedness, SPUP has managed to maneuver the changes in the educational landscape with commendable results. This can be credited to the creative and innovative strategies adopted by SPUP to implement the Internationalization Program. The internationalized curricula and instructional modalities have attracted international students and partners. Local students were similarly captivated to the value of Paulinian education which makes a difference globally.

The smooth convergence of the inter-cultural and inter-religious differences among the international and local students was achieved by the policy on religious and academic freedom, the adherence to the tenets of inter-faith dialogue, and the development and practice of inter-cultural competence. This did not happen overnight but through systematic interventions and activities. Somehow, this touched on the people-to-people interaction and collaboration to promote the harmonious relations and cooperation among the ASEAN nations.

The citizenship and character dimensions in the development of global competencies are assets in the over-all education of the person. The human values and service orientation would matter a lot in the equation of success in life and career. Citizenship training and character formation can help to successfully navigate the complexities of the $21^{\text {st }}$ century global and knowledge-based economy. Paulinian education holistically inculcates character and value formation, citizenship education, and academic service learning. The students have positively identified the importance of citizenship education in the ASEAN Regional Integration and internationalization in the local, global and digital contexts. In this era of globalization and advance technology, it is imperative for the schools to prepare the students and graduates to become responsible global digital citizens.

\section{References}

Ang, M. (Jun 2017). Internationalization of St. Paul University Philippines: A framework to develop intercultural competence for global education. Asian Academic Research Journal of Social Sciences and Humanities, $4(6)$.

Berse, P. (2017). Internationalization indicators of higher education in ASEAN+6: Trends, challenges, future directions. Retrieved

from http://www.ateneo.edu/.../internationalization-indicators-higher-education-asean6-trends-ch

Bialik, M., Bogan, M. et. al. (2015). Character education for the 21st Century: What should students learn? Center for Curriculum Redesign. Boston, Massachusetts.

Club, L. (2016). Analysis paper on ASEAN integration in education. Retrieved from http://www.academia.edu/21671253/ANALYSIS_PAPER_ASEAN_INTEGRATION_IN_EDUCATION

Crockett, L.W. (2017). What is a global digital citizen and why does the world need them?. Global Digital Citizenship Foundation. Retrieved from https://globaldigitalcitizen.org/global-digitalcitizenworldneed

Crockett, L.W., \& Churches, A. (2017). Growing global digital citizens: Better practices that build better learners. Solution Tree Press. Bloomington, IN., USA.

Del Rosario, R. (2015). Education's responsibilities in integrated Asean. Philippine Daily Inquirer. October 10, 2015.

Farahani, M.F. (2014). The role of global citizenship education in world peace and security. Procedia- Social and Behavioral Sciences, 934-938. https://doi.org/10.1016/j.sbspro.2014.01.323

Fatoni, A. (2017). The strategy of character education in globalization era. International Journal of Scientific \& Technology Research, 6(4), 112-114.

Finelli, J., quoted in Mansilla, V., \& Jackson, A. (2011). Educating for global competence: Preparing our youth to engage the world. Asia Society. 725 Park Avenue New York, NY 10021.

Fullan, M., \& Langworthy, M. (2014). A Rich Seam: How new pedagogies find deep learning. London.

Macaranas, F. (2015). ASEAN 2015: Challenges and opportunities for educators. Retrieved from http://asean.aim.edu/research/presentations/_asean_challenges_and_opportunities_for_educators/

Ontario Citizenship Education Framework Worksheet-Edugains. (2012). Retrieved from http://www.edugains.ca/resourcescurrimpl/secondary/cws/citizenshipeducationframeworkworksheet 
Pacete, V. (2015). Asean integration and K-12 program. SunStar Bacolod. Tuesday, April 21, 2015 newspaper issue.

Parker, P. (2014). The six Cs of character education. Retrieved from www.sec-ed.co.uk/best-practice/the-six-cs-of-character-education

Rhoades, R., \& Szelényi, K. (2011). Global citizenship and the university: Advancing social life and relations in an interdependent world. Stanford University Press: Palo Alto, CA, USA.

Roy, C. (2011). Value education in higher education institute: A precondition for sustainable development. MRPA Paper No. 41264. Retrieved from https://mpra.ub.uni-muenchen.de/41264/

Torno, B. (2017). DepEd: Philippine education meets ASEAN requirements. SunStar Baguio, March 24, 2017 issue.

UGC. (2003). Higher education in India: Issues, concerns and new directions, recommendations of UGC golden jubilee seminar.

\section{Copyrights}

Copyright for this article is retained by the author(s), with first publication rights granted to the journal.

This is an open-access article distributed under the terms and conditions of the Creative Commons Attribution license (http://creativecommons.org/licenses/by/4.0/). 